\title{
Prevalence of Maternal Mortality and Clinical Course of Maternal Deaths in COVID-19 Pneumonia-A Cross-Sectional Study
}

\author{
Mahesh Asalkar $^{1} \cdot$ Smita Thakkarwad $^{1} \cdot$ Ilaaf Rumani $^{1} \cdot$ Nitika Sharma $^{1}$
}

Received: 2 July 2021 / Accepted: 6 August 2021 / Published online: 6 October 2021

(c) Federation of Obstetric \& Gynecological Societies of India 2021

\begin{abstract}
Introduction After initial studies suggested that pregnant women were not at a higher risk of complications due to COVID-19 infection. Recent investigations from Sweden and the US have indicated that pregnant and postpartum women are at increased risk of severe complications associated with COVID-19. This study aims to find out the prevalence of maternal mortality and the clinical course of maternal mortality cases due to COVID-19 pneumonia.

Methodology A cross-sectional study was conducted from May 1st, 2020, to April 30th, 2021, at Postgraduate Institute and YCM Hospital Pimpri Pune (Maharashtra), a dedicated COVID hospital during COVID pandemic. During study period, all pregnant women who were diagnosed to have COVID-19 infection by RT PCR/Rapid Antigen Test were admitted and were enrolled for the study.

Aim To audit the maternal mortality due to COVID-19 infection.

Primary To estimate the prevalence of maternal mortality due to COVID-19 infection in obstetric patients.

Secondary To systematically study and analyze the clinical course of infection in mothers who had mortality due to COVID19 pneumonia. Data collected in standard format regarding Demography, clinical presentation, need for ICU/HDU, CXR findings, laboratory parameters and cases with maternal mortality were studied in detail to fulfill the study objectives.

Results Among 871 COVID-19 cases diagnosed during pregnancy, nine patients had maternal mortality due to covid pneumonia. There was no obvious obstetric cause for mortality in these cases. The prevalence of maternal mortality was 0.01 $(1.03 \%)$. Cases with maternal mortality were mostly in 3rd Trimester (5 of 9 cases) and presented with moderate to severe illness with breathlessness and myalgia in all 9 cases, cough and fever in 7 out of 9 cases, Tachypneoa was noted in all patients. Saturation below 90 in 6 cases and below 94 in 3 cases. Chest X-ray showed bilateral lung affection in all 9 cases. Leukocytosis with raised N:L ratio was predominantly seen, thrombocytopenia noted in 5 cases and elevated levels of acute phase reactants and inflammatory markers such as CRP, S. ferritin, ESR, LDH, D-dimer and S. fibrinogen was observed. None of the study participants received vaccine for COVID-19.

Conclusions COVID-19 pneumonia is an additional toll for maternal mortality. Obstetric patients in 2nd and 3rd trimester having COVID-19 infection with late presentation to hospital, moderate to severe disease (RR > 30 min), with raised inflammatory markers (N:L ratio, CRP, Ferritin, d-Dimer, etc.) at presentation, having bilateral lung affection are at risk of poor maternal outcome.
\end{abstract}

Keywords Maternal mortality $\cdot$ COVID-19 $\cdot$ Viral pneumonia

Professor \& Head, Department of Obstetrics and Gynaecology, PGI-YCMH Pimpri, Pune, MS, India; Associate Professor, Department of Obstetrics and Gynaecology, PGI-YCMH Pimpri, Pune, MS, India; Junior Resident, Department of Obstetrics and Gynaecology, PGI-YCMH Pimpri, Pune, MS, India; Junior Resident, Department of Obstetrics and Gynaecology, PGI-YCMH Pimpri, Pune, MS, India

Mahesh Asalkar

mahesh@asalkarclinic.com

Extended author information available on the last page of the article

\section{Introduction}

On March 11, 2020, the WHO officially announced that the COVID-19 had become a global pandemic (1). Most of the studies available on COVID-19 have evaluated the impact of the disease in general population, and there are insufficient data on effect of COVID-19 in pregnancy. Pregnant women are more susceptible to acquire viral respiratory infections and severe pneumonia due to physiological changes in their 
immune and cardiopulmonary systems during pregnancy (2, $3)$.

COVID-19 infection in pregnancy more likely presents as mild symptomatic infection or it may be asymptomatic, and the risk of COVID-19 infection for pregnant women may be much lower than SARS or middle east respiratory syndrome (4).

After initial studies conducted on impact of COVID-19 infection on pregnancy suggested that pregnant women were not at a higher risk of complications due to COVID-19 infection (5), recent studies conducted at Sweden and the United States have shown that pregnant and postpartum women are at increased risk of severe complications associated with COVID-19 (6,7).

This study is an endeavor to find out the prevalence of maternal mortality and the clinical course of maternal mortality cases due to COVID 19 pneumonia.

\section{Methodology}

A cross-sectional study was conducted from May 1st, 2020, to April 30th, 2021, at PCMC'S Postgraduate Institute and YCM Hospital Pimpri Pune (Maharashtra) which was declared as dedicated COVID hospital during COVID pandemic. During study period, all pregnant women (antenatal, intrapartum, and postpartum) who were diagnosed to have COVID-19 infection by RT PCR/Rapid antigen test were admitted at the study institution and were enrolled for the study.

\section{Aim}

To audit the maternal mortality due to COVID-19 infection.

\section{Objectives}

\section{Primary}

To estimate the prevalence of maternal mortality due to COVID-19 infection in obstetric patients.

\section{Secondary}

To systematically study and analyze the clinical course of infection in mothers who had mortality due to COVID-19 pneumonia.

\section{Inclusion Criteria}

1. All antepartum, intrapartum and postpartum women who were diagnosed to have COVID-19 infection by RT PCR/Rapid antigen test during the study period.

2. Gestational age from conception to 6 weeks postpartum were included in the study.

\section{Exclusion Criteria}

1. Patient admitted with COVID-19 infection however referred to other institute were not included in the study because of non-availability of records related to outcome.

2. Refusal of consent for participation in the study.

\section{Technique/Methodology}

We conducted a prospective, single-center, cross sectional study at PCMC'S PGI and Y C M Hospital, Pune (tertiary teaching hospital) which was dedicated Covid Hospital during the study period. Sample size was all pregnant women diagnosed to have SARS-CoV-2 infection with gestation age from conception upto 6 weeks postpartum admitted during study period of 1 year. An Informed consent of the admitted pregnant women taken for participation in study. (Table 1Data collection tool) Data collected in standard format as mentioned in the data collection tool. In cases where patient was not able to give consent due to medical reasons, access to medical records was requested. Ethics committee was requested for waiver off the consent in such cases. Critical cases which had maternal mortality were analyzed.
Table 1 Data collection tool

\begin{tabular}{ll}
\hline Demographic data & Age, BMI, socioeconomic status \\
\hline $\begin{array}{l}\text { Clinical presentation and need for ICU with } \\
\text { duration }\end{array}$ & $\begin{array}{l}\text { Symptomatology on admission, oxygen saturation at pres- } \\
\text { entation, duration of hospitalization/ICU stay, admission } \\
\text { to death interval } \\
\text { Obstetric history }\end{array}$ \\
& $\begin{array}{l}\text { and mode of delivery(if applicable), postpartum status, } \\
\text { obstetric high risk }\end{array}$ \\
Medical history & Co-morbidities, symptoms at presentation, clinical findings \\
Laboratory investigations & CRP/FBC/N:L ratio/D-dimer/LDH/Ferritin/ESR/fibrinogen \\
Chest X-ray & Serial Chest X-rays \\
Treatment & As per ICMR/Government of India Guidelines \\
Maternal outcome & Stable/discharged/died \\
\hline
\end{tabular}




\section{Ethical Aspect}

Institutional Ethics Committee approval was obtained \& confidentiality of the data maintained throughout the study.

\section{Statistical Analysis}

Statistical analysis was done using Epi-info7 software.

\section{Data Collection}

Data were collected in uniform, consistent and reliable manner by trained qualified doctors with the use of standard proforma. Key variables as mentioned in the data collection tool were documented.

\section{Results}

Table 2 shows total 9 cases of maternal mortality due to COVID-19 pneumonia recorded among 871 cases reflecting $0.01(1.03 \%)$ prevalence of maternal mortality in our study. 6 of 9 cases $(66 \%$ ) (case 1, 3, 4, 7, 8, 9) were between 25 and 35 years of age which is a most common reproductive age. Normal BMI noted in 6 cases (case1, 3, 5, 6, 7, 9). Most of mortality cases 5 out of 9 were from middle socioeconomic class. Five cases out of 9 (case 1, 2, 3, 4, 8) were in third trimester.

Table 3 shows common presenting features among maternal mortality cases were breathlessness and myalgia in all nine patients. Out of these 9 cases, 7 cases $(2,3,4$, $5,6,7,8)$ also had typical features such as cough, fever, along with breathlessness and myalgia, while 2 cases (case 7, 9) had uncommon features at the time of presentation such as loss of taste and smell however breathlessness and myalgia was a common feature in these cases. According to disease severity classification based on clinical features (Respiratory rate, Oxygen saturation etc.) by National Task force for Covid 19, 6 out of 9 (case 1, 3, 5, 6, 8,9 ) were in severe category while 3 (case $2,4,7$ )patients were in moderate category at the time of presentation. All nine patients required HDU/ICU at the time of admission and all 9 cases had history of affection of at least one family members due to COVID-19 and none of the cases were vaccinated.

Table 4 shows laboratory parameters in maternal mortality cases. Leukocytosis was noted in 6 cases (case $4,5,6,7,8,9$ ) while TLC was normal in 3 cases (case 1,2,3) however lymphopenia with raised $\mathrm{N}: \mathrm{L}$ ratio was common finding among all 9 patients. Thrombocytopenia was seen in 5 cases (case 1,2,3,6,8) while platelet count was normal in 4 cases ( case 4,5,7,9). Inflammatory markers such as CRP was moderately raised in all 9 cases, S. Ferritin was raised in was raised in all 9 cases while $\mathrm{LDH}$ was raised 7 cases (case 1,2,4,5,7,8,9)and normal in 2 cases (case 3,6 ). D-dimer was raised in 7 cases (case 1,2,3,5,6,7,8), and it was normal in 2 cases (case 4,9). Fibrinogen was raised in 5 cases (case 1,3,4,5,6) and normal in 4 cases (case 2,7,8,9).

Table 5 shows all 9 cases had bilateral lung affection.

Table 2 Prevalence of maternal mortality and demographic features of 9 cases

\begin{tabular}{|c|c|c|c|c|c|c|c|c|c|}
\hline Total number & of COVID po & itive(antenata & labor, postp & tum) admissi & $\mathrm{n}$ during stud & period & & & 871 \\
\hline Total number & of maternal n & ortality cases & ue to COVID & 19 during stu & y period & & & & 9 \\
\hline Prevalence of & maternal mor & ality due to $\mathrm{C}$ & VID-19 duri & g study perioc & & & & & 0.01 \\
\hline $\begin{array}{l}\text { Character- } \\
\text { istic }\end{array}$ & Case 1 & Case 2 & Case 3 & Case 4 & Case 5 & Case 6 & Case 7 & Case 8 & Case 9 \\
\hline Age (years) & 28 & 36 & 24 & 32 & 38 & 36 & 29 & 23 & 33 \\
\hline BMI $\left(\mathrm{kg} / \mathrm{m}^{2}\right)$ & 23 & 28.6 & 22.6 & 18 & 22.9 & 21.7 & 23.9 & 29.4 & 23.5 \\
\hline $\begin{array}{l}\text { Socio- } \\
\text { economic } \\
\text { status }\end{array}$ & $\begin{array}{l}\text { Middle } \\
\text { socio- } \\
\text { economic } \\
\text { class }\end{array}$ & $\begin{array}{l}\text { Upper } \\
\text { socio- } \\
\text { economic } \\
\text { class }\end{array}$ & $\begin{array}{l}\text { Middle } \\
\text { socio- } \\
\text { economic } \\
\text { class }\end{array}$ & $\begin{array}{l}\text { Lower } \\
\text { socio- } \\
\text { economic } \\
\text { class }\end{array}$ & $\begin{array}{l}\text { Middle } \\
\text { socio- } \\
\text { economic } \\
\text { class }\end{array}$ & $\begin{array}{l}\text { Middle } \\
\text { socio- } \\
\text { economic } \\
\text { class }\end{array}$ & $\begin{array}{l}\text { Lower } \\
\text { socio- } \\
\text { economic } \\
\text { class }\end{array}$ & $\begin{array}{l}\text { Upper } \\
\text { socio- } \\
\text { economic } \\
\text { class }\end{array}$ & $\begin{array}{l}\text { Middle soci- } \\
\text { oeconomic } \\
\text { class }\end{array}$ \\
\hline $\begin{array}{l}\text { Gestational } \\
\text { age at } \\
\text { admission }\end{array}$ & 34 weeks & 34 weeks & 33 weeks & 38 weeks & 5 weeks & 26 weeks & 27 weeks & 39 weeks & $\begin{array}{l}\text { Post op } \\
\text { case of } \\
\text { exploratory } \\
\text { laprotomy } \\
\text { in a c/o } \\
\text { ruptured } \\
\text { ectopic } \\
\text { pregnancy }\end{array}$ \\
\hline
\end{tabular}


Table 3 Clinical presentation of the patients

\begin{tabular}{|c|c|c|c|c|c|c|c|c|c|}
\hline Characteristic & Case 1 & Case 2 & Case 3 & Case 4 & Case 5 & Case 6 & Case 7 & Case 8 & Case 9 \\
\hline \multicolumn{10}{|l|}{ Symptoms } \\
\hline Dyspnea & + & + & + & + & + & + & + & + & + \\
\hline Cough & + & + & + & - & + & + & + & + & - \\
\hline Fever & - & + & + & + & + & + & + & + & - \\
\hline Sore throat & - & + & + & - & + & - & + & + & - \\
\hline Myalgia & + & + & + & + & + & + & + & + & + \\
\hline Anosmia & - & - & - & + & - & + & - & - & + \\
\hline Dysgeusia & - & - & - & + & - & + & - & - & + \\
\hline Others & Headache & Diarrhea & Diarrhea & - & - & Diarrhea & Headache & Diarrhea & - \\
\hline $\begin{array}{l}\text { Severity of infec- } \\
\text { tion at the time } \\
\text { of admission * }\end{array}$ & Severe & Moderate & Severe & Moderate & Severe & Severe & Moderate & Severe & Severe \\
\hline $\begin{array}{l}\text { Time from onset } \\
\text { of symptoms } \\
\text { till hospitaliza- } \\
\text { tion }\end{array}$ & 9 days & 3 days & 4 days & 4 days & 6 days & 7 days & 5 days & 9 days & 3 days \\
\hline \multicolumn{10}{|l|}{$\begin{array}{l}\text { Obstetric high } \\
\text { risk }\end{array}$} \\
\hline No high risk & + & - & - & - & + & - & - & - & - \\
\hline Previous LSCS & - & - & - & - & - & + & - & + & - \\
\hline Anemia & - & - & + & + & - & + & + & - & + \\
\hline Ruptured ectopic & - & - & - & - & - & - & - & - & + \\
\hline Twins & - & + & - & - & - & - & - & - & - \\
\hline $\begin{array}{l}\text { Atleast one fam- } \\
\text { ily member is } \\
\text { affected }\end{array}$ & Yes & Yes & Yes & Yes & Yes & Yes & Yes & Yes & Yes \\
\hline $\begin{array}{l}\mathrm{SpO} 2 \text { at admis- } \\
\text { sion }\end{array}$ & $77 \%$ & $93 \%$ & $86 \%$ & $94 \%$ & $74 \%$ & $88 \%$ & $91 \%$ & $84 \%$ & $82 \%$ \\
\hline $\begin{array}{l}\text { Respiratory rate } \\
\text { on admission }\end{array}$ & 36 & 26 & 32 & 24 & 36 & 30 & 28 & 38 & 30 \\
\hline $\begin{array}{l}\text { Need for Oxygen } \\
\text { at admission }\end{array}$ & Yes & Yes & Yes & Yes & Yes & Yes & Yes & Yes & Yes \\
\hline $\begin{array}{l}\text { ICU/HDU } \\
\text { requirement }\end{array}$ & Yes & Yes & Yes & Yes & Yes & Yes & Yes & Yes & Yes \\
\hline $\begin{array}{l}\text { Admission to } \\
\text { death interval }\end{array}$ & 1 day & 2 days & 9 days & 15 days & 2 days & 10 days & 9 days & 9 days & 4 days \\
\hline $\begin{array}{l}\text { Obstetric Inter- } \\
\text { vention }\end{array}$ & Not done & LSCS & Not done & LSCS & Not done & Not done & Not done & LSCS & $\begin{array}{l}\text { Exploratory } \\
\text { laparotomy }\end{array}$ \\
\hline $\begin{array}{l}\text { Indication of } \\
\text { surgical inter- } \\
\text { vention }\end{array}$ & NA & $\begin{array}{l}\text { Non-reassuring } \\
\text { CTG }\end{array}$ & NA & MSAF & NA & NA & NA & $\begin{array}{l}\text { Oligohydram- } \\
\text { nios, Non- } \\
\text { reassuring } \\
\text { CTG }\end{array}$ & Ruptured ectopic \\
\hline $\begin{array}{l}\text { Vaccination } \\
\text { status }\end{array}$ & Not taken & Not taken & Not taken & Not taken & Not taken & Not taken & Not taken & Not taken & Not taken \\
\hline
\end{tabular}

\section{Discussion}

On March 11, 2020, WHO officially announced that the COVID-19 infection had become a global pandemic.[1] Even though the clinical manifestations and treatment monitoring of COVID-19 pneumonia patients have been studied extensively, there are few studies on pregnant women with COVID-19 pneumonia[8].Earlier, in the
COVID-19 pandemic, it was not clear whether pregnancy itself was a risk factor for severe illness from COVID-19. But, now there is growing evidence that pregnant women may be at increased risk of severe illness from COVID-19 infection compared with non-pregnant women, particularly in the third trimester of pregnancy. It is highly important to systematically investigate the clinical characteristics and outcomes of pregnant women with COVID-19 to 
provide strong guidelines for prevention, treatment, and management[4].

A brief systematic review on maternal mortality in COVID 19 studied by Marcos mentions six countries had reported maternal deaths due to COVID-19 by July 1, 2020 [8].Three high-income countries (France, UK, and US) and three middle-income countries (Brazil, Iran, and Mexico) [9-14]. The total number maternal deaths reported were 160 . In high-income countries twenty-two maternal deaths were documented, and 138 in middle income countries (124 from Brazil, representing $77.5 \%$ of all maternal deaths reported in the literature). Looking at these figures of maternal deaths due to COVID-19 infection, it is reasonable to assume that worldwide figures of maternal deaths due to COVID-19 must be even higher.

We studied 871 pregnant women affected with COVID19 infection at dedicated COVID hospital, and we recorded nine maternal deaths in our study (Table2). Prevalence of maternal mortality in our study was $0.01(1.03 \%)$. Out of 9 cases 6 (case $1,3,4,7,8,9$ ) were in the young reproductive age group between 25 and 35 years. BMI was normal in 6 cases (case 1,3,5,6,7,9) while it was more in 2 cases (case 2,8 ) and one case (case 4) had less than normal BMI.

On $9^{\text {th }}$ January, 2021, a preprint (not yet peer reviewed) was released with results from two large COVID-19 in pregnancy registries the PAN COVID registry and the AAP SONPM registry[15].The PAN COVID registry recorded suspected or confirmed COVID-19 cases at any stage in pregnancy (in UK and ten other countries) and AAP SONPM registry reported maternal covid 19 cases around the time of birth (from 14 days before and 3 days after birth). Maternal mortality was uncommon in both registries. Maternal death occurred in 3 of 651 women confirmed with COVID-19 (0.46\%) in PAN COVID registry and in 5 of 2398 women with COVID-19(0.21\%) in the AAP SONPM registry. Our study had higher prevalence $(1.03 \%)$ as compared to the prevalence mentioned in these two registries. (0.46\% PANCOVID and $0.21 \%$ AAP SONPM).

Majority of COVID-19 infection in pregnancy will be asymptomatic. Preg COV-19 Living systematic review reporting on universal screening in pregnancy found $74 \%$ (95\% CI 51-93) of women were asymptomatic [16]. While another study from the USA reported that $86 \%$ of women who were admitted in labor and who tested positive for SARS-CoV-2 were asymptomatic. [17]. Most symptomatic women experience only mild or moderate cold/flu-like symptoms. [18] The PregCOV-19 systematic review has so far included over 64000 pregnant women worldwide with suspected or confirmed COVID-19 (reported prior to 29 November 2020) [16]. In this review, the most common symptoms of COVID-19 in pregnant women were cough (41\%) and fever (40\%). Less frequent symptoms were dyspnea (21\%), myalgia (19\%), loss of sense of taste (14\%) and diarrhea (8\%). Pregnant women with COVID-19 were less likely to have fever or myalgia than non-pregnant women of the same age. The PRIORITY (Pregnancy Coronavirus Outcomes Registry) study, an ongoing prospective cohort study of pregnant women from the United States, found the most prevalent first symptoms in infected women were cough (20\%), sore throat (16\%), myalgia (12\%) and fever (12\%). In this group of 594 symptomatic women, one-quarter had persistent symptoms 8 or more weeks after onset [19].

As we are reporting case series of 9 maternal mortality cases from our study (Table3), we noted all these 9 cases were symptomatic at the time of presentation. In these 9 cases, breathlessness and myalgia was present in all cases while cough and fever was noted in 7 out of 9 patients. Two patients in our series had loss of taste and smell however

Table 4 Shows the laboratory results of the cases

\begin{tabular}{|c|c|c|c|c|c|c|c|c|c|c|}
\hline Investigation & Case 1 & Case 2 & Case 3 & Case 4 & Case 5 & Case 6 & Case 7 & Case 8 & Case 9 & $\begin{array}{l}\text { Normal reference range } \\
\text { for pregnancy [Ref 31] }\end{array}$ \\
\hline WBC & 8.3 & 8.5 & 5.6 & 25.9 & 24.9 & 20.3 & 17.2 & 18.1 & 18.6 & $\begin{array}{l}5.6-16.9 \\
\times 10^{3} / \mathrm{mm}^{3}\end{array}$ \\
\hline Platelet count & 107 & 114 & 110 & 186 & 273 & 110 & 183 & 111 & 224 & $\begin{array}{l}146-429 \\
X 10^{3} / \mathrm{mm}^{3}\end{array}$ \\
\hline N:L Ratio & 5.2 & 8.5 & 4.3 & 36.08 & 13 & 10 & 24.8 & 6.2 & 8 & - \\
\hline CRP & 84 & 272 & 145 & 303 & 254 & 143 & 89 & 120 & 150 & $0.4-8 \mathrm{mg} / \mathrm{l}$ \\
\hline LDH & 1745 & 877 & 368 & 1230 & 667 & 453 & 551 & 734 & 666 & $82-524 \mathrm{U} / \mathrm{L}$ \\
\hline D-Dimer & 5980 & 5990 & 4824 & 465 & 27,470 & 10,073 & 30,700 & 7000 & 658 & $130-1700 \mathrm{ng} / \mathrm{mL}$ \\
\hline Ferritin & 314 & 185 & 642 & 1124 & 189 & 223 & 729 & 935 & 693 & 0-166 ng/ml \\
\hline Fibrinogen & 651 & 478 & 650 & 779 & 640 & 874 & 467 & 542 & 469 & $373-619 \mathrm{mg} / \mathrm{dL}$ \\
\hline
\end{tabular}

Bold face is used to represent ferritin, an acute phase reactant which is raised in inflammatory conditions like COVID-19. It is also a part of COVID panel for the investigations in case of suspected/confirmed cases of COVID. In our case, increased levels correlate with the severity of the condition 
Table 5 Radiological Features showing lung affection in COVID-19 among mortality cases

\begin{tabular}{|c|c|c|c|c|c|c|c|c|}
\hline & Case 1 & Case & & Case 3 & & Case 4 & & Case 5 \\
\hline \multicolumn{9}{|l|}{ CXR image } \\
\hline \multirow[t]{2}{*}{ CXR findings } & $\begin{array}{l}\text { Evidence of inhomo- } \\
\text { geneous opacities in } \\
\text { bilateral mid zones } \\
\text { and lower zones and } \\
\text { right upper zone s/o } \\
\text { pneumonitis }\end{array}$ & $\begin{array}{r}\text { Evid } \\
\text { enc } \\
\text { in } 1 \\
\text { s/o } \\
\text { tiol } \\
\text { Evid } \\
\text { me }\end{array}$ & $\begin{array}{l}\text { nce of homog- } \\
\text { us patchy opacities } \\
\text { ilateral lung fields } \\
\text { patchy consolida- } \\
\text { nce of cardio- } \\
\text { aly }\end{array}$ & \multicolumn{2}{|c|}{$\begin{array}{l}\text { Evidence of patchy } \\
\text { opacities in bilateral } \\
\text { lung fields s/o pneu- } \\
\text { monitis } \\
\text { Evidence of cardio- } \\
\text { megaly }\end{array}$} & \multicolumn{2}{|c|}{$\begin{array}{l}\text { Evidence of homog- } \\
\text { enous opacities in } \\
\text { bilateral lung fields } \\
\text { s./o pneumonitis } \\
\text { Evidence of cardio- } \\
\text { megaly }\end{array}$} & $\begin{array}{l}\text { Evidence of } \\
\text { Homogenous } \\
\text { opacities in right } \\
\text { lung fields s/o } \\
\text { pneumonitis }\end{array}$ \\
\hline & Case 6 & & Case 7 & & Case 8 & & Case 9 & \\
\hline \multicolumn{9}{|l|}{ CXR image } \\
\hline CXR findings & \multicolumn{2}{|c|}{$\begin{array}{l}\text { Evidence of inhomogene- } \\
\text { ous opacities in right lung } \\
\text { fields s/o pneumonitis } \\
\text { Borderline Cardiomegaly }\end{array}$} & \multicolumn{2}{|c|}{$\begin{array}{l}\text { Evidence of inhomogeneous } \\
\text { opacities in bilateral mid } \\
\text { zones and lower zones } \\
\text { (right }>\text { left) s/o pneumo- } \\
\text { nitis }\end{array}$} & \multicolumn{2}{|c|}{$\begin{array}{l}\text { Evidence of Homogenous } \\
\text { opacities in bilateral lung } \\
\text { fields s/o pneumonitis }\end{array}$} & \multicolumn{2}{|c|}{$\begin{array}{l}\text { Evidence of inhomogeneous } \\
\text { opacities in bilateral mid } \\
\text { zones and lower zones s/o } \\
\text { pneumonitis }\end{array}$} \\
\hline
\end{tabular}

breathlessness and myalgia was a common feature in these 2 cases.

In a cohort study conducted by José Villar, they found the presence of any COVID-19 symptoms was associated with increased morbidity and mortality. Specifically, severe pregnancy and neonatal complication rates were highest in women if fever and shortness of breath were present, reflecting systemic disease; their presence for 1 to 4 days was associated with severe maternal and neonatal complications [20]. These findings correspond with our study suggesting that presence of any symptom of COVID-19 increases the morbidity and mortality compared to asymptomatic infection with SARS-CoV -2 virus.

Out of 9 deaths (Table 3 ) recorded 5 (case 1,2,3,4,8) were noted in $3^{\text {rd }}$ trimester. Pregnancy especially in third trimester may be a high-risk factor for poor maternal outcome in COVID-19 infection. Out of 5 cases in third trimester 3 cases (case $2,4,8$ ) were delivered by cesarean section and 2 cases (case 1,3) were preterm ( $<37$ weeks), decision for termination of pregnancy was challenging due to prematurity and conservative management was preferred with hope for better maternal outcome with COVID treatment guidelines however patients had mortality in due course of time. Neonatal outcome was good, and babies were negative for COVID-19 and discharged.

In the UK Obstetric Surveillance System (UKOSS study), most women were hospitalized in the third trimester or peripartum (bearing in mind that admission at term to give birth will contribute to this distribution [21]. Hazari et al. in the study of critically ill pregnant women with COVID-19 has also reported 5 cases out of 7 critically ill cases in the $3^{\text {rd }}$ trimester of pregnancy [22].

Admission to death interval (Table3)was less than $72 \mathrm{~h}$. in 3 cases (case 1,2,5), $72 \mathrm{~h}-1$ week in 1 case (case 9), 1-2 week in 4 cases (case 3,6,7,8) and $>2$ week in 1 case (case 4). We also enquired about COVID-19 affection among the family members of the deceased and all 9 cases had at least one member affected with COVID-19 infection; however, there was no mortality among other family members. This may suggest association of severe form of COVID-19 in pregnancy could be related to bad outcome.

During pregnancy, there are alterations in cellular immunity, especially in the second and third trimester, that is generally thought to protect the fetus from "rejection" by the 
mother. These changes in the cellular immunity can predispose the pregnant women to infection with certain pathogens such as viruses, fungi, and tuberculosis [23, 24].

There are some physiological changes of pregnancy that can predispose the pregnant woman to a severe course of pneumonia (Table 6). These include elevation of the diaphragm by up to $4 \mathrm{~cm}$, decrease in functional residual capacity, an increase in oxygen consumption, and an increase in lung water [23, 25]. These physiologic changes in the respiratory system associated with pregnancy, decrease the ability of the pregnant woman to clear respiratory secretions and aggravate airway obstruction associated with pulmonary infections. The elevation of the diaphragm and the associated decrease in functional residual capacity, along with the increased oxygen consumption during pregnancy, makes the pregnant woman less able to tolerate even brief periods of hypoxia, particularly in the third trimester.

Among 9 maternal deaths reported in our institute common finding was delayed presentation to hospital from the onset of symptoms. All 9 cases reported after $48 \mathrm{~h}$ of onset of symptoms and 3 of them were presented after 7 day while 6 reported between 3 and 7 day after onset of symptoms. Clinical disease severity was moderate in 3 cases and severe in 6 cases.

Obstetric management of critically ill COVID-19 infection is challenging especially in the third trimester. We had 5 cases (gestation age between 33 and 39 weeks) and decision of delivery by LSCS was taken in 3 of 5 cases for fetal indication while in 2 cases conservative management as per covid treatment guidelines was continued. In patients delivered by LSCS neonatal outcome was good and all 3 babies were discharged with negative RT PCR report. All cases were managed by multidisciplinary team involving intensivist, pulmonologist, anesthesiologist and physiotherapist.

For pregnant women in the third trimester who have COVID-19 infection, an individualized assessment should be undertaken by the MDT to decide whether emergency

Table 6 Alterations in pregnancy predisposing to an increased incidence and mortality from pneumonia

\section{Immunologic changes}

Reduced lymphocyte proliferative response

Diminished cell-mediated cytotoxicity

Reduced number of helper T cells

Reduced lymphokine response to alloantigens

Hormonal changes

Elevation of progesterone, human chorionic gonadotropin, alpha fetoprotein, and cortisol may also inhibit cell-mediated immune function

Physiologic changes

Increase in oxygen consumption

Increase in lung water

Elevation of diaphragm

Aspiration more likely in labor and delivery cesarean birth or IOL should be prioritized, either to facilitate maternal resuscitation (including the need for prone positioning) or because of concerns regarding fetal health. If maternal stabilization is required, delivery can be undertaken safely as this is the priority, as it is for other maternal emergencies. Any urgent intervention for birth is indicated for fetal reasons, then delivery should be expedited as for usual obstetric indications, as long as the mother's condition is stable. When iatrogenic preterm birth is required, administration of antenatal corticosteroids to promote fetal lung maturation and magnesium sulfate for fetal neuroprotection, should be considered. Urgent intervention for birth should not be delayed for their administration[26]. Prone positioning of patients with moderate to severe acute respiratory distress syndrome (ARDS) can improve respiratory function and has been recommended for the care of patients with COVID-19 [27].

None of the 871 patients admitted at our hospital received vaccine against COVID-19. At the time of writing this article, two vaccines (covishield and covaxin) were available for use in the India under vaccination program however use of vaccines was mainly restricted to senior citizens in initial phase followed by adults above 18 age group however it was not recommended for use in pregnancy.

The Joint committee on vaccination and Immunization (JCVI) have updated their guidelines on 16th April 2021 and are now advising that all pregnant women should be offered the COVID-19 vaccine as the rest of the population at the same time, based on their age and clinical risk group. There is no reason to think that the vaccines will not protect pregnant women effectively against COVID-19. As the COVID-19 vaccines have not been tested in pregnant women, we cannot say for sure that the vaccine will have worse side-effects in pregnant women [26].

Although there is limited UK data regarding COVID19 vaccination in pregnancy, there is credible real-world data from the United States-where around 90,000 pregnant women have been vaccinated mainly with mRNA vaccines, such as Pfizer-BioNTech and Moderna which have not raised any safety concerns regarding COVID-19 vaccine in pregnancy.

In the absence of data, we cannot be $100 \%$ sure that vaccines will not cause adverse events in pregnancy. However, this uncertainty needs to be weighed against the risk of COVID-19 in pregnancy.

Table 4 Leukocytosis was seen in $67 \%$ cases $(n=6)$ with increased N:L Ratio (>3.5) in 100\% $(\mathrm{n}=9)$. A study by Tjendra et al. suggested association of leukocytosis characterized by neutrophilia and increased NLR with severe disease [28]. Their study also suggested that thrombocytopenia to be seen more likely in severe or critically ill and fatal cases, which was seen in $55.5 \%$ of cases $(n=5)$. All cases, $100 \%$, showed elevated CRP levels and raised ferritin 
levels. Both these biomarkers being acute phase proteins, they are considered one of the earliest host responses to viral or bacterial infection. Tjendra et al. did a comparison study between survivors and nonsurvivors in COVID-19 and found an upward trend of CRP and ferritin in nonsurvivors, similar to the findings in our study. In addition, a study by Liu $\mathrm{F}$ et al. found that patients with CRP $>41.8 \mathrm{mg} / \mathrm{L}$ were more likely to develop severe disease which was also reflected in this study [29]. Serum LDH was raised in 78\% $(n=7)$, similar to the findings of Tjendra et al. which was seen in severe and critically ill patients. The major coagulation indices, i.e., D-dimer and fibrinogen levels were elevated in $78 \%(n=7)$ and $56 \%(n=5)$ cases with values $>3$ times the upper limit of D-dimer seen in $67 \%$ cases. Tjendra et al. and several other studies cited by them also found significantly higher values of these coagulation indices in critically ill patients. Tjendra et al. suggested neutrophilia, thrombocytopenia, elevated D-dimer and high NLR as predictors for case mortality with patients showing high values of CRP and LDH more likely to develop sepsis, have rapid disease progression, and experience early death (within 3 days of admission). The similar trend in all the above-mentioned parameters was seen in this study. Table 5 shows all 9 cases had bilateral lung affection in all 9 cases.

\section{Strength and Weakness}

We strongly advise the readers that this Perspective be considered preliminary. As the pandemic continues, there will be more data available that could lead to significant changes in the scenario of COVID-19 with pregnancy.

This being a small case series, we are not intending to comment on case fatality rates, attributable risk and relative risk of maternal mortality following SARS-CoV-2 infection. This may require cohort study with more stringent population wide surveillance of COVID-19 in pregnancy. Also, our data are from single center and our results during the study period mainly suggest mortality due to COVID-19 strains involved regionally in India. As no mutation data source or studies were carried out, results may differ in other regions due to difference in virulence of strains.

We took a rigorous approach in collecting primary source data and documenting maternal deaths exclusively related to COVID-19. Our study have demonstrated that COVID-19 maternal mortality is not zero. Also, cases described here does not have any contributing obstetric cause for maternal death, this suggests cautious attitude in management of pregnancy with COVID-19 infection even in asymptomatic to mild cases under the wrong assumption of mild affection by COVID-19 with pregnancy.

In our study, 7 out of 9 cases had at least one adult family member affected with COVID-19 however most of them had mild to moderate disease with good recovery with no mortality, this may suggest that pregnancy especially in 2nd and 3rd trimester itself may be high-risk factor for poor maternal outcome.

\section{Recommendations}

Guidelines and Recommendations for COVID-19 needs constant review and updation as the pandemic continues.

Special Registry Nationwide or Institution wise maintenance of data and constant review and audit of maternal outcome in COVID-19 infection will help to improve maternal outcome.

Each hospital concerned with maternity services need to have MDT approach (obstetrician, physician/intensivist, Anesthetiologist, physiotherapist) in managing COVID-19 infection with pregnancy.

\section{Conclusion}

COVID-19 pneumonia is an additional toll for maternal mortality and one of the indirect cause for maternal mortality which needs to be considered in future along with other causes of maternal mortality. Obstetric patients in 2nd and 3rd trimester having COVID-19 infection with late presentation to hospital, moderate to severe disease ( $R R>30 \mathrm{~min}$ ), with raised inflammatory markers (N:L ratio, CRP, Ferritin, d-Dimer etc.) at presentation, having bilateral lung affection are at risk of poor maternal outcome.

Acknowledgements We would like to thank Dr. Mangesh Londhe Asst. Professor pathology department and Dr. Mrs Bansode radiology department for providing necessary inputs of various data of COVID-related cases. Our sincere gratitude goes to all supervisors, data collectors, ANMs, study participants with their family members for their cooperation and support. We would like to thank Dean, Dr Rajendra Wable and Board of Review Chairman Dr. Mrs Ambike for granting necessary permissions and providing facilities for conducting study.

Author's contributions MA, ST, IR, NS involved in all processes of this research work. All authors read and approved the final manuscript. MA and ST conceived, designed the experiments and analyzed the data. MA, ST, IR, NS performed the experiments. MA, ST, IR, NS contributed materials/analysis tools. MA, ST, IR wrote the paper.

Funding No Funding received.

\section{Declarations}

Conflict of interest None to declare.

\section{References}

1. WHO. Director-General's opening remarks at the media briefing on COVID19. 2020. 
2. Li Q, Guan X, Wu P, et al. Early transmission dynamics in Wuhan, China, of novel coronavirus-infected pneumonia. N Engl J Med. 2020;382(13):1199-207.

3. Huang C, Wang Y, Li X, et al. Clinical features of patients infected with 2019 novel coronavirus in Wuhan, China. The Lancet. 2020;395(10223):497-506.

4. Mullins E, Evans D, Viner RM, et al. Coronavirus in pregnancy and delivery: rapid review. Ultrasound Obstet Gynecol. 2020;55:586-92.

5. Chen L, et al. Clinical characteristics of pregnant women with Covid-19 in Wuhan, China. N Eng J Med. 2020;382:e100.

6. Collin J, Byström E, Carnahan A, Ahrne M. Pregnant and postpartum women with SARS-CoV-2 infection in intensive care in Sweden. Acta ObsGynecol Scand. 2020;99:819-22.

7. Ellington S, Strid P, Tong VT, et al. Characteristics of women of reproductive age with laboratory-confirmed SARS-CoV-2 infection by pregnancy status-United States. Morb Mortal Wkly Rep. 2020;69:769-75

8. Liu D, Li L, Wu X, et al. Am J Roentogenol. 2020;215:127-32. https://doi.org/10.2214/AJR.20.23072.

9. Nakamura-Pereira M, BetinaAndreucci C, de Oliveira MM, et al. Worldwide maternal deaths due to COVID-19: a brief review. Int J Gynecol Obstet. 2020;151(1):148-50.

10. Ellington S, Strid P, Tong VT, et al. Characteristics of women of Reproductive age with laboratory-confirmed SARS-CoV-2 infection by pregnancy status-United States, January 22-June 7, 2020. Morb Mortal Wkly Rep. 2020;69:769-75.

11. Kayem G, Alessandrini V, Azria E, et al. A snapshot of the Covid19 pandemic among pregnant women in France. J Gynecol Obstet Hum Reprod. 2020;4:101826.

12. Knight M, Bunch K, Vousden N, et al. Characteristics and outcomes of pregnant women hospitalised with confirmed SARSCoV-2 infection in the UK a national cohort study using the UK Obstetric Surveillance System (UKOSS). BMJ. 2020;369:m2107.

13 Takemoto MLS, Menezes MO, Andreucci CB, et al. The tragedy of COVID-19 in Brazil: 124 maternal deaths and counting. Int J Gynaecol Obstet. 2020. https://doi.org/10.1002/ijgo.13300.

14. Lumbreras-Marquez MI, Campos-Zamora M, Lizaola-Diaz de Leon H, Farber MK. Maternal mortality from COVID-19 in Mexico. Int J Gynecol Obstet. 2020;150:266-7.

15. Hantoushzadeh S, Shamshirsaz AA, Aleyasin A, et al. Maternal death due to COVID-19 disease. Am J Obs Gynecol. 2020;223:109.E1-109.E1.

16. Mullins E, Hudak M, Banerjee J, et al. Pregnancy and neonatal outcomes of COVID-19-coreporting of common outcomes from the PAN-COVID and AAP SONPM registry. MedRxiv. 2021. https://doi.org/10.1101/2021.01.06.21249325.

17. Allotey J, Stallings E, Bonet M, et al. Clinical manifestations, risk factors, and maternal and 87 perinatal outcomes of coronavirus disease 2019 in pregnancy: living systematic review and metaanalysis. BMJ. 2020;370:m3320.

18. Reale SC, Lumbreras-Marquez MI, King CH, et al. Patient characteristics associated with SARSCoV-2 infection in parturients admitted for labour and delivery in Massachusetts during the spring 2020 surge: a prospective cohort study. Paediatr Perinat Epidemiol. 2021;35:24-33.

19. Public Health England. COVID-19: investigation and initial clinical management of possible cases 2020. https://www.gov.uk/gover $\mathrm{nment} /$ publications/wuhan-novel-coronavirus-initialinvestigationof-possible-cases/investigation-and-initial-clinical-managementof-possible-casesof-wuhan-novel-coronavirus-wn-cov-infection. Accessed 2021 Feb 12.

20. Afshar Y, Gaw SL, Flaherman VJ, et al. Clinical presentation of coronavirus disease 2019 (COVID-19) in pregnant and recently pregnant people. Obstet Gynecol. 2020;136:1117-25. https://doi. org/10.1097/AOG.0000000000004178.
21 Villar J, Ariff S, Gunier RB, et al. Maternal and neonatal morbidity and mortality among pregnant women with and without COVID19 infection: the INTERCOVID multinational cohort study. JAMA Pediatr. 2021. https://doi.org/10.1001/jamapediatrics.2021.1050.

22. Vousden N, Bunch K, Morris E, et al. The incidence, characteristics and outcomes of pregnant women hospitalized with symptomatic and asymptomatic SARS-CoV-2 infection in the UK from March to September 2020: a national cohort study using the UK Obstetric Surveillance System (UKOSS). PLoS ONE. 2021;16(5):e0251123.

23. Hazari KS, Paulose L, Kurien N, et al. Clinical characteristics, management, maternal and neonatal outcome among seven severe and critically ill pregnant women with COVID-19 pneumonia. Clin J Obstet Gynecol. 2020;3:158-66.

24. Rodrigues J, Niederman MS. Pneumonia complicating Pregnancy. Clin Chest Med. 1992;13:679-91.

25. Lederman MM. Cell mediated immunity and pregnancy. Chest. 1984;86:6S-9S

26. Rigby FB, Pastorek JG II. Pneumonia during Pregnancy. Clin Obstet Gynecol. 1996;39:107-19.

27. Royal College of Obstetricians and gynaecologists Guidelines. Corona virus (COVID 19) infection in pregnancy: information for health care professionals; version $13(19 \mathrm{Feb} 2021)$. https://www. rcog.org.uk/globalassets/documents/guidelines/2021-02-19-coron avirus-covid-19-infection-in-pregnancy-v13.pdf.

28. World Health Organisation. Clinical management of severe acute respiratory infection when novel coronavirus $(\mathrm{nCoV})$ infection is suspected 2020 [https://www.who.int/publications-detail/clinicalmanagement-of-severe-acute-respiratory-infection-when-novelcoronavirus-(ncov)-infection-is-suspected]. Accessed 2021 Feb 12.

29. Tjendra Y, Al Mana AF, Espejo AP, et al.. Predicting disease severity and outcome in COVID-19 patients: a review of multiple biomarkers. Arch Pathol Lab Med. 2020;144(12):1465-74. https://doi.org/10.5858/arpa.2020-0471-SA.

30. Liu F, Li L, Xu M, et al. Prognostic value of interleukin-6, C-reactive protein, and procalcitonin in patients with COVID-19. J Clin Virol. 2020;127: 104370. https://doi.org/10.1016/j.jcv.2020. 104370.

31. Abbassi-Ghanavati M, Greer LG, Cunningham FG. Pregnancy and laboratory studies: a reference table for clinicians. Obstet Gynecol. 2009;114(6):1326-31.

Publisher's Note Springer Nature remains neutral with regard to jurisdictional claims in published maps and institutional affiliations.

\section{About the Author}

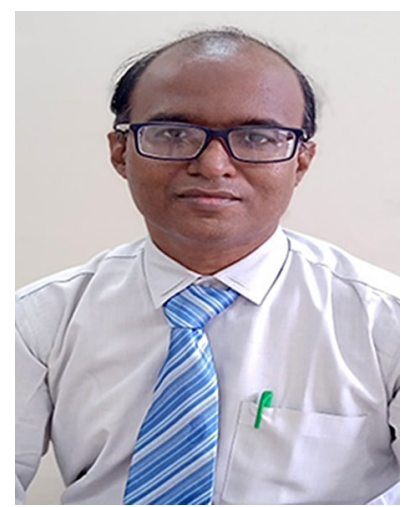

Mahesh Asalkar (MD,DNB, FCPS,DGO) is working as Professor and Head at Department of Obstetrics and Gynaecology at Postgraduate Institute and YCM Hospital Pimpri Pune 18 affiliated to Maharashtra University of Health Sciences Nasik. He has more than 15 years teaching experience to Undergraduate and Postgraduate Students. He is recognized teacher and examiner for Undergraduate and Postgraduate examinations for various Universities in India. Dr. Asalkar 
has completed Postgraduate Diploma in Bioethics from Indira Gandhi National Open University. He is also trained in Basic and advanced Research Methodology and is a recognized faculty for conducting research methodology workshops for medical professionals. He is a clinician with special interest teaching and research aspect of medical profession. His area of Interest includes High Risk Pregnancy, Infertility and laparoscopy. He has also worked as Principal Investigator for various research Projects in his speciality. He has done his research work in High risk pregnancy especially in rural part of India where limited resources are available to provide health care services. Perinatal outcome in Preterm Labour, Pregnancy Induced hypertension, Twin pregnancy, Intra-uterine growth retardation, placental pathology and maternal mortality in COVID are few of his research work. He has many publications to his credit in various national and international journals.

\section{Authors and Affiliations}

\section{Mahesh Asalkar $^{1} \cdot$ Smita Thakkarwad $^{1} \cdot$ Ilaaf Rumani $^{1} \cdot$ Nitika Sharma $^{1}$}

1 Department of Obstetrics and Gynaecology, PGI-YCMH

Pimpri, Pune, MS 411018, India 